\title{
Hierarquia política e poder no Estado do Brasil: o governo-geral e as capitanias, 1654-1681
}

Francisco Carlos Cardoso Cosentino*

\section{RESUMO}

Este trabalho analisa os governos do Estado do Brasil, identificando e diferenciando suas hierarquias e poderes, caracterizando a relação entre os governadores-gerais e os governadores e capitães-mores das capitanias dessa parte da monarquia pluricontinental lusa, fossem elas de donatário ou régias, anexas ou principais. Conclui, ao contrário do que se tem afirmado, a diferenciação de sua autoridade e o poder e a supremacia dos governadores-gerais.

Palavras-chave: Estado do Brasil; governadores ultramarinos; hierarquia de poder; capitanias de donatário e régias; capitanias principais e anexas.

\begin{abstract}
This paper analyzes the governments of the state of Brazil, identifying and differentiating their hierarchies and powers, and characterizing the relationship between the governors general and governors and captains-general of captaincies in that part of the pluricontinental Portuguese monarchy, be it a royal or a grantee captaincy, annexed or major. Contrary to what has been stated, the paper exposes a differentiation of their authority and power, with a supremacy of the governor general's power.
\end{abstract}

Keyword: State of Brazil; overseas governors; hierarchy of power; royal and grantee captaincies; major and annexed captaincies.

DOI - http://dx.doi.org/10.1590/2237-101X016031007

Artigo recebido em 30 de abril de 2015 e aprovado para publicação em 15 de junho de 2015.

Este trabalho apresenta os resultados de pesquisa vinculados ao edital Demanda Universal da FAPEMIG 2012 e 2014.

* Doutor em História pela Universidade Federal Fluminense (UFF) e professor na Universidade Federal de Viçosa (UFV). Belo Horizonte, MG, Brasil. E-mail: fcosentino@ufv.br. 
O estudo sobre os governadores-gerais e os governadores e capitães-mores das capitanias padece de uma interpretação dominante na historiografia brasileira resultado da análise elaborada na década de 40 do século XX por Caio Prado Junior. Segundo ele, "o título do governador diferia: capitão-general e governador, nas [capitanias] principais, capitão-mor de capitania (não confundir com capitão-mor de ordenanças), ou simplesmente governador, nas demais", pois o governador do Rio de Janeiro (e antes o da Bahia), que "tinha o título altissonante mais oco de Vice-Rei do Brasil", detinha "poderes, em princípio, [que] não eram maiores que os de seus colegas de outras capitanias, e não se estendiam, além da sua jurisdição territorial de simples capitão-general". ${ }^{1}$ Essa interpretação historiográfica, que claramente secundarizava e minimizava os governantes da conquista portuguesa da América, marca até nossos dias, entre os mais variados historiadores e concepçóes historiográficas, a compreensão dessa parte da vida do Estado do Brasil e mesmo do Estado do Maranhão.

Essas concepçôes de Prado Junior sobre organização política foram articuladas com a sua compreensão do chamado sentido da colonização e, nas décadas de 1960 e 1970, se desdobraram nas concepçóes do Antigo Sistema Colonial, construindo uma compreensão geral do estatuto das conquistas portuguesas onde a metrópole e os monarcas "absolutistas" portugueses presidiam a vida das suas subalternas terras americanas. ${ }^{2}$ Dizendo a mesma coisa, só que em tempos mais atuais, o sistema colonial se apresenta primeiramente "como um tipo particular de relaçóes políticas", sendo assim, podemos compreendê-las definindo-se a partir de dois elementos, que se constituem de forma complementar: "um centro decisório (metrópole) e um outro subordinado (colônia)" ${ }^{3}$

Por todas essas razóes, o entendimento da ordem política instituída pela monarquia pluricontinental portuguesa nas suas conquistas ultramarinas, particularmente as americanas, secundarizou, reduziu e marginalizou os governos e os governadores ultramarinos, com consequências para a historiografia, e, na prática, reproduzindo concepções que, se foram importantes para a historiografia brasileira na década de 1940, hoje se mostram insuficientes. Essa compreensão é repetida até hoje por historiadores de diversas correntes teóricas, explicitamente ou não, muitas vezes reforçando, mesmo que de forma encoberta, uma compreensão absolutista da monarquia portuguesa e europeia, apesar das já consagradas e consistentes críticas a essa caracterização. ${ }^{4}$ Os governos ultramarinos lusos merecem tratamento

\footnotetext{
${ }^{1}$ PRADO JUNIOR, Caio. Formação do Brasil Contemporâneo. 14. ed. São Paulo: Brasiliense, 1976, p. 306. 2 "[...] configura-se a etapa intermediária que já se vai tornando usual chamar-se de capitalismo mercantil, pois é o capital comercial gerado mais diretamente na circulação de mercadorias, que anima toda a vida econômica no Estado absolutista, com extrema centralização do poder real, que de certa forma unifica e disciplina uma sociedade organizada em 'ordens' e executa uma política mercantilista de fomento do desenvolvimento da economia de mercado, interna e externamente [...]” (NOVAIS, Fernando A. Estrutura e dinâmica do Antigo Sistema Colonial. 6. ed. São Paulo: Brasiliense, 1993, p. 21-22).

${ }^{3}$ PUNTONI, Pedro. O Estado do Brasil. Poder e política na Bahia colonial - 1548-1700. São Paulo: Editorial Alameda, 2013, p. 16.

${ }^{4}$ Como exemplos temos o trabalho de Stone (STONE, Lawrence. La crisis de la aristocracia, 1558-1641. Ma-
} 
historiográfico que incorpore as concepçóes renovadas, ${ }^{5}$ destacadamente aquelas vinculadas ao estudo do político e da política, ${ }^{6}$ por isso, acreditamos que, antes de avançarmos, duas questóes precisam ficar demarcadas no espaço desse artigo.

Em primeiro lugar, Portugal, durante o Antigo Regime, organizou-se de acordo com uma forma de governo que apresentava um regime político adequado e condicionado, na sua construção, ao desenvolvimento da sua História. Nesse sentido, não basta falar de Estado português, Estado moderno ou generalidades desse tipo, mesmo que acompanhadas de referências a diversificadas historiografias, muitas vezes sem qualquer identidade com os argumentos apresentados. O fato é que Portugal, durante o Antigo Regime, tinha uma forma de governo que estava ordenado segundo um regime político. A questão que se propõe é, qual são eles? Qual é a forma portuguesa de governo e o regime político português? Da mesma maneira que ressaltar a particularidade da escravidão na conquista portuguesa da América e, assim, caracterizar a organização da sua produção econômica e suas consequências sociais é fundamental, também o é caracterizar sua ordem política, inclusive relacionando-a aos outros aspectos da vida social.

Nesse sentido, contribuindo para responder a essas indagaçóes, resgatamos duas caracterizaçóes que têm sido usuais nas análises contemporâneas. A monarquia pluricontinental como forma de governo e a dinâmica sinodal, jurisdicional e corporativa, como o regime político desse reino, ou seja, as "instituiçôes que regulam a luta pelo poder e o seu exercício, bem como a prática dos valores que animam tais instituiçôes". 7 Náo consideramos satisfatória a estratégia seguida pelos que ainda compreendem o mundo colonial sustentado em dicotomias econômicas e políticas, para dissimular a já criticada caracterização de absolutismo, falando de "Estado moderno", "grande máquina do Estado", 8 como fazem alguns,

dri: Alianza Editorial, 1985) sobre a aristocracia inglesa, cujo relacionamento com a monarquia demonstra a situação de protagonismo régio e limitação de poder. Le Roy Ladurie (LADURIE, Emmanuel Le Roy. $O$ Estado Monárquico. França, 1460-1610. São Paulo: Companhia das Letras, 1995), em estudo sobre a monarquia francesa, ele identificou os limites para a atuação do poder real resultante da atuação de um conjunto de poderes intermediários. Apesar da fachada absolutista, o Estado Moderno francês era uma sociedade de ordens/estados. Fora da corte e da sede do governo, a monarquia francesa tinha um sistema de administração em parte e fracamente centralizado. E, em sua La Espana Imperial, J. H. Elliott afirmou que a "España era, por lo tanto, un Estado plural, no unitario, y estaba formado por una serie de patrimonios separados, regidos de acuerdo con sus leys características propias" (ELLIOTT, J. H. La Espana Imperial. 1469-1716. Barcelona: Ediciones Vicens-Vives, 1998, p. 85).

${ }^{5}$ Um ponto de partida brasileiro e referência de renovação são os trabalhos de João Fragoso na História social e de Maria de Fátima Gouvêa, na História política e social, destacadamente o livro Antigo Regime nos trópicos. ${ }^{6}$ Ver: PUJOL, Xavier Gil. Tiempo de política. Perspectivas historiográficas sobre la Europa moderna. Barcelona: Publicacions i Edicions Universitat de Barcelona, 2006.

${ }^{7}$ LEVI, Lucio. Regime Político. In: BOBBIO, Norberto; MATTEUCCI, Nicola; PASQUINO, Gianfranco. Dicionário de Política. 5. ed. Brasília: Edunb, 1993, 1081. Ver essa discussão em COSENTINO, Francisco Carlos. Monarquia pluricontinental, o governo sinodal e os governadores-gerais do Estado do Brasil. In: GUEDES, Roberto (Org.). Dinâmica Imperial no Antigo Regime Português. Rio de Janeiro: Mauad, 2011, p. 67-82.

${ }^{8}$ PUNTONI, Pedro. O Estado do Brasil, op. cit., p. 22-23. 
mesmo que recobrindo seus argumentos com aparente erudição, ou mesmo aqueles que questionam as análises nacionalistas e caem na armadilha da imprecisão, ao falarem de "Estado imperial". "Também é insuficiente tratar a monarquia portuguesa como "Estado" ou "Estado europeu entre os séculos XV e XVIII, do período que, de modo talvez impreciso, se convencionou chamar de Antigo Regime", ${ }^{10}$ ou então, falar de "égide da monarquia" "Coroa portuguesa". Reconheçamos o Estado em Portugal, estrutura de poder e dominação. Mas, qual era sua forma? Qual seu regime político? Essas caracterizaçóes, muitas vezes construídas a partir da negação de outras, não dão fisionomia e conteúdo ao Portugal dos Quinhentos e Seiscentos.

Em segundo lugar, percebemos que certos recortes de análise, mesmo que construídos em bases renovadas para a historiografia da história colonial, ao enfatizarem os aspectos sociais da monarquia pluricontinental portuguesa - como faz António Manuel Hespanha que, em vários trabalhos, chama a monarquia portuguesa de corporativa —, acabam por minimizar os aspectos sinodal e jurisdicional que "regulam a luta pelo poder e o seu exercício", ${ }^{12}$ conforme já indicamos anteriormente. Sim, a monarquia portuguesa é corporativa, mas, também, sinodal e jurisdicional, e também na sua extensão para as suas conquistas ultramarinas.

A concessão de mercês remunerando serviços e agraciando súditos já foi analisada em diversos trabalhos e não vamos explorar esse aspecto da monarquia pluricontinental portuguesa. Entretanto, como já nos demonstrou Marcello Loureiro no seu livro, ${ }^{13}$ e, recentemente, em sua tese, ${ }^{14}$ a dinâmica sinodal foi um dos vértices do processo político do reino luso, que tinha nas decisóes colegiadas tomadas em conselhos diversos, muitas vezes, mistos, o mecanismo essencial do seu processo decisório. Hierarquizada a partir do Conselho de Estado, espaço das decisões da grande política da monarquia lusa e espraiado nos outros conselhos, assim eram tomadas as decisóes no Portugal do Antigo Regime.

Essa dinâmica colegiada era um procedimento tão arraigado na vida política portuguesa que se estendeu para as conquistas ultramarinas e, em várias situaçóes e com formas diversas, a Câmara da Bahia e outras personalidades detentoras de poder na cidade eram chamadas pelo governador-geral para se manifestarem a respeito de assuntos específicos e relevantes,

\footnotetext{
${ }^{9}$ BETHENCOURT, Francisco. Configuraçôes políticas e poderes locais. In: BETHENCOURT, Francisco; CURTO, Diogo Ramada. A expansão marítima portuguesa, 1400-1800. Lisboa/Portugal: Ediçóes 70, 2010, p. 207-264.

${ }^{10}$ SOUZA, Laura de Mello. O sol e a sombra. Política e administração na América portuguesa do século XVIII. São Paulo: Companhia das Letras, 2006, p. 48.

${ }^{11}$ RICUPERO, Rodrigo. A formação da elite colonial, Brasil c. 1530-c. 1630. São Paulo: Alameda Editorial, 2009, p. 139.

${ }^{12}$ LEVI, Lucio. Regime Politico, op. cit., p. 1081.

${ }^{13}$ LOUREIRO, Marcello J. Gomes. A gestão do labirinto. Rio de Janeiro: Apicuri, 2012.

${ }^{14}$ LOUREIRO, Marcello J. Gomes. Iustitiam Dare. A gestão da monarquia pluricontinental. Conselhos superiores, pactos, articulaçôes e o governo da monarquia portuguesa (1640-1668). Tese (doutorado) — Programa de Pós-Graduação em História Social, Instituto de História, Universidade Federal do Rio de Janeiro, 2013.
} 
exercendo papéis de aconselhamento desses governantes, cumprindo as funçóes sinodais características da monarquia lusa. Um exemplo foi a reunião realizada no palácio de governo em 7 de agosto de 1662 reunindo "o senado da [Câmara] e [nobreza] e Povo dela", 15 convocada por Francisco Barreto, para que juntos deliberassem sobre a contribuição do dote da rainha da Inglaterra e da paz com a Holanda, levantada no Estado do Brasil, com valores definidos pelas diversas câmaras dessa conquista e que foi arrecadado por vários anos. Outra forma era a ida do governador à casa da Câmara, como a de Alexandre de Sousa Freire, em 7 de abril de 1669, onde, juntamente com os oficiais dela e "os oficiais maiores da milícia desta praça”, foi requerido pelo procurador daquela casa que o governador taxasse o "preço do açúcar branco e mascavo pelo que justo fosse" ${ }^{16}$ E ainda podemos encontrar a câmara tocando "a campa da cidade e chamar cidadãos dela e mais povo" 17 para que, "todos juntos", se manifestassem sobre o Termo de Resolução apresentado pelo governador-geral, João Rodrigues de Vasconcelos e Sousa, conde de Castelo Melhor, em 10 de março de 1650, sobre o aumento do valor que seria pago pelas pipas de vinho vendidas na cidade para manutenção das suas tropas e sua defesa. A resolução, uma vez tomada, era também assinada pelo governador. Em todos esses casos, poder local, nobreza da terra, oficiais diversos e o governador-geral, "todos juntos", negociaram e deliberaram sobre várias questóes a respeito da governação do Estado do Brasil. A mesma iniciativa de promover deliberaçóes colegiadas podemos constatar da portaria baixada em maio de 1675 pelo governador-geral Afonso Furtado de Mendonça, instruindo que se “ajustasse na sua presença o Prov ${ }^{\text {or }}$ Mor da Fazenda, convocando aos Capitães e Mestres dos navios, os Homens de negócio e Lavradores"18 para juntos deliberarem sobre o frete do açúcar.

Se no Estado do Brasil, as decisóes colegiadas que assessoravam os governadores-gerais eram tomadas de maneira "informal" pelo "senado da [Câmara] e [nobreza] e Povo dela" para que "todos juntos" deliberassem, no Estado da Índia, o Conselho de Estado era uma realidade desde o final do século XVI, ganhando forma explícita no início do século XVII. ${ }^{19}$ $\mathrm{Na}$ América Espanhola, por sua vez, os vice-reis tinham nas Audiências, tribunais esses que nas capitais eram presididos pelos vice-reis, a semelhança do Tribunal da Relação da Bahia presidido pelo governador-geral, o colegiado de aconselhamento que cumpria esse papel. ${ }^{20}$

\footnotetext{
${ }^{15}$ Documentos Históricos do Arquivo Municipal. Atas da Câmara, 1659-1669. 4. v. Bahia, Prefeitura do Município do Salvador, 1649, p. 136-140.

${ }^{16}$ Documentos Históricos do Arquivo Municipal. Atas da Câmara, 1659-1669, op. cit., p. 409-411.

${ }^{17}$ Documentos Históricos do Arquivo Municipal. Atas da Câmara, 1641-1649. 2. v. Bahia, Prefeitura do Município do Salvador, 1949, p. 118.

${ }^{18}$ Arquivo Nacional do Rio de Janeiro, doravante denominado ANRJ - Códice 538, v. 4, fl. 7.

${ }^{19}$ Não se tem uma data precisa sobre o funcionamento do Conselho de Estado do Estado da Índia, é possível que tenha sucedido ao Conselho dos Capitães. Tem-se notícia dele em 1591 quando, por carta régia, ficou estabelecido que o vice-rei ouvisse em conselho os "fidalgos e outras pessoas de experiência" deste Estado. Em 1604 o Conselho ganha forma efetiva, fixados os seus membros. Ver PISSURLENCAR, Panduronga S. S. Assentos do Conselho do Estado, vol. I (1618-1633). Goa (Bastorá): Tipografia Rangel, 1953.

20 "La Audiencia en América disfrutó de más facultades que la de España. [...] Aquí tenían además, atribuciones de carácter político, porque en sí consistía un gabinete ministerial del Virrey” (RUBIO MAÑÉ, José
} 
Por fim, essa era uma monarquia jurisdicional que não podia "ser visto[a] predominantemente pela ótica da norma, da teoria ou da lei, que muitas vezes permanecia letra morta e outras tantas se inviabilizava ante a complexidade e a dinâmica das situações específicas". ${ }^{21}$ Ao contrário da crítica de Souza representada nessa passagem, era, conforme António Manuel Hespanha, o criticado pela referida autora, o mundo da centralidade de um direito [...] decalcado das várias leis que o mundo conhecia — a lei divina, a lei da natureza externa das sociedades, mas também da lei interna das almas dos homens, tanto a natureza das instituiçôes como [...] a tradição feita lei, o exemplo que fez fama[...]. ${ }^{22}$

Com esse significado, patentes, cartas régias e regimentos, de diversos ofícios, superiores ou não na hierarquia político-administrativa, foram emitidos, muitas vezes resultado de debates e consultas aos órgáos colegiados da monarquia, ${ }^{23}$ ordenando a governação do reino e das conquistas do ultramar. É por essas razóes que não podemos conceber nem a legislação como um amontoado desconexo de determinaçóes particulares e casuísticas de regras que se acrescentam umas as outras sem obedecerem a plano algum de conjunto, nem que os governadores ultramarinos nunca tiveram nitidamente caracterizadas suas competências e jurisdiçôes, conforme recorrentemente muitos indicam explicita ou implicitamente. Patentes, regimentos, instruçôes e outros instrumentos normatizadores, segundo a lógica da escolástica e da dinâmica sinodal, corporativa e jurisdicional da monarquia lusa, transplantados para as conquistas americanas, como foi e talvez, não podia deixar de ser, ordenaram o governo e as atribuiçóes dos administradores lusos no Estado do Brasil, estilo e costume, como muitos documentos afirmavam.

Com esse ponto de vista, nos últimos quinze anos, investigaçóes fundadas numa compreensão renovada da história política sobre os governadores ultramarinos são realizadas, particularmente sobre os governadores-gerais. Os trabalhos resultantes dessas pesquisas têm incorporado e desdobrado o entendimento da monarquia pluricontinental portuguesa como um regime político sinodal, jurisdicional e corporativo, base da ordenação política estendida

Ignacio. El Virreinato, I Orígenes y jurisdicciones, y dinámica social de los virreyes. México: Fondo de Cultura Económica, 1992, p. 51. Ver também, RIVERO RODRÍGUEZ, Manuel. La edad de oro de los virreyes. Madri: Ediciones Akal, 2011).

${ }^{21}$ SOUZA, Laura de Mello. O sol e a sombra, op. cit., p. 56.

${ }^{22}$ HESPANHA, António Manuel. Depois do Leviathan. In: Caleidoscópio do Antigo Regime. São Paulo: Alameda, 2012, p. 10.

${ }^{23}$ Os regimentos são tão importantes para a ordenação da vida política e administrativa que, sua elaboração, circulavam pelos conselhos da sinodal monarquia portuguesa. Assim sendo, o regimento do governo-geral do Brasil mereceu atenção do Conselho de Estado, como podemos ver nos dois ofícios enviados pelo secretário de Estado ao visconde de Vila Nova de Cerveira convocando-o para "acabar de ver o regimento do Brasil" (Biblioteca da Ajuda, doravante denominada BA. 52-IX-9, fl. 52) e para "se acabar de ajustar o regimento do Brasil” (BA. 52-IX-9, fl. 76). E o Conselho Ultramarino, em um parecer (Pernambuco. Arquivo Histórico Ultramarino, doravante denominado AHU-ACL-CU, 015, caixa 9, doc. 830), e uma consulta (Pernambuco. AHU-ACL- CU, 015, caixa 9, doc. 909), se manifesta ao monarca a respeito dos regimentos do governo de Pernambuco e do Estado do Brasil no que diz respeito ao provimento de ofícios. 
ao ultramar, destacadamente o Estado do Brasil, e sinalizam para o protagonismo dos governadores-gerais e seus sucessores no século XVIII, os vice-reis. Hoje, o que se coloca é refletir sobre o papel desempenhado pelos governadores das capitanias do Rio de Janeiro e Pernambuco, assim como dos capitães-mores das outras capitanias. Assim, o tema do trabalho que se segue pretende abordar as relaçóes entre essas instâncias de poder — governadores-gerais, governadores e capitães-mores de capitanias — analisando a natureza das capitanias — régias e hereditárias — a sua posição hierárquica — principais e anexas — assim como o relacionamento político e as hierarquias de poder existentes entre governadores-gerais, governadores de capitanias e capitães-mores.

\section{Governo-geral e capitanias: hierarquias, poderes e regimentos}

Antes, depois e por causa do trabalho referência de Caio Prado Junior, compreensóes limitadas dos poderes e das relaçóes entre os governadores ultramarinos foram desenvolvidas. Nesse campo, respeitando e contextualizando a importância de seus trabalhos, temos diversos historiadores - Francisco A. de Varnhagen, ${ }^{24}$ Capistrano de Abreu, ${ }^{25}$ Pedro Calmon, ${ }^{26}$ Eulália Maria Lahmeyer Lobo, ${ }^{27}$ Graça Salgado ${ }^{28}$ — que em épocas diferentes, com formações e preocupaçôes historiográficas distintas, apresentaram a temática da centralização el ou do absolutismo, como justificativa para o governo-geral. Por outro lado, Calmon, Lobo e Salgado, em trabalhos elaborados a partir dos anos cinquenta do século XX, associam essa centralização à limitação dos poderes "do governador-geral do Brasil [...] pela existência dos capitães-mores", ${ }^{29}$ pois, a monarquia "não pudera eliminar os beneficiários que possuíam as terras hereditariamente, e continuaram com certos direitos jurisdicionais e com as rendas estipuladas nos forais", ${ }^{30}$ conforme Lobo, mas que era compartilhado, com nuances, pelos outros autores. ${ }^{31}$

\footnotetext{
${ }^{24}$ VARNHAGEN, Francisco Adolfo. História Geral do Brasil. Tomo Primeiro. 9. ed. São Paulo: Melhoramentos, 1975.

${ }^{25}$ ABREU, Capistrano. Capitulos de História Colonial. 7. ed. Belo Horizonte: Itatiaia; São Paulo: Publifolha, 2000.

${ }^{26}$ CALMON, Pedro. História do Brasil. As origens (1500-1600). São Paulo: Cia Editora Nacional, 1951, v. 1, p. 224.

${ }^{27}$ LOBO, Eulália Maria Lahmeyer. Processo administrativo ibero-americano. Rio de Janeiro: Biblioteca do Exército, 1962, p. 261.

${ }^{28}$ SALGADO, Graça (Coord.). Fiscais e meirinhos. A administração no Brasil Colonial. 2. ed. Rio de Janeiro: Nova Fronteira, 1985, p. 51.

${ }^{29}$ LOBO, Eulália Maria Lahmeyer. Processo administrativo ibero-americano, op. cit., p. 263.

${ }^{30}$ Idem.

${ }^{31}$ Essa percepção da centralização e das limitaçôes impostas pelo sistema donatorial é bastante disseminada na historiografia, como já ressaltamos e está presente em outras obras como a História administrativa do Brasil, editada pelo Dasp em 1955, particularmente em GUEDES, João Alfredo Libânio. História Administrativa do Brasil. Da restauração a D. João V. v. IV, 2. ed. Brasília/DF: Funcep, 1984. Com alcance escolar temos também, reunindo professores do Colégio D. Pedro II, AVELLAR, Helio de Alcântara. História administrativa e econômica do Brasil. Rio de Janeiro: Fename, 1970.
} 
Obra de referência, como a de Caio Prado Junior, Os donos do poder, elaborado no final dos anos cinquenta do século XX por Raimundo Faoro, indicava sobre a criação do governo-geral, que com ele "completava-se a obra de incorporação e absorção dos assuntos públicos da colônia à autoridade real, por meio de seus agentes diretos", ${ }^{32}$ com a constituição de uma "carapaça burocrática, vinculada à metrópole, obediente ao rei, criou a cúpula da ordem política". ${ }^{33}$ Na percepção de Raimundo Faoro, o governo-geral "dispóe de poderes escritos de grande profundidade e alcance, embora não logre subjugar as capitanias e os focos de autoridade local, as câmaras, em comando vertical e completo". ${ }^{34}$

Nos últimos anos, trabalhos que poderiam incorporar a renovação da História política, suas interfaces com a história social e cultural e as possibilidades da pesquisa empírica, não o fizeram e continuam a reproduzir concepçóes que ao reduzirem os poderes, as hierarquias e as dinâmicas políticas da governação no ultramar da monarquia pluricontinental portuguesa, apequenam esse espaço essencial da vida das conquistas ultramarinas, a política e o político.

Esse é o caso dos autores que concebem um "sentido da colonização" e submetem o governo das conquistas ultramarinas a um monarca absolutista, e, mesmo que "modernizem" a interpretaçáo marxista do autor - Caio Prado Junior, e do seu intérprete mais contemporâneo, Fernando Novais - com análises de matiz weberiano, reproduzem a dicotomia metrópole $\times$ colônia que esvazia e empobrece as possibilidades de apreensão da dinâmica política e social das localidades, territórios e governo-geral da América lusa. Esse também é o caso daqueles que ao afirmarem que "as capitanias gozavam de considerável autonomia em relação ao governador, que só podia impor a sua autoridade em questôes de defesa", ${ }^{35}$ concluem ser "difícil estabelecer uma cadeia hierárquica que o governador controlasse". ${ }^{36}$

O curioso é que, quando resgatamos relatos de época, como o de frei Vicente Salvador, cronista do século XVII, encontramos descriçóes que a historiografia contemporânea deixou para trás, e que foram pertinentemente compreendidas pelo cronista ao entender que o primeiro governador-geral foi mandado à Bahia para "fazer nela uma cidade, que fosse como coração no meio do corpo, donde todas se socorressem e fossem governadas" ${ }^{\prime \prime}$ e trouxe o "título de governador de todo o estado do Brasil, dando-lhe grande alçada de poderes e regimento em que quebrou os que tinha concedido a todos os outros capitáes". ${ }^{38}$

Inspirado em frei Vicente Salvador, apoiado na compreensão da monarquia pluricontinental portuguesa de bases corporativas, jurisdicionais e sinodais, e sustentando os argumentos na pesquisa empírica, contrariamos a análise construída e já mencionada ante-

\footnotetext{
${ }^{32}$ FAORO, Raymundo. Os donos do poder. 1. v. 10. ed. Sáo Paulo: Globo, 1996, p. 146.

${ }^{33}$ Idem.

${ }^{34}$ Ibidem, p. 182.

${ }^{35}$ BETHENCOURT, Francisco. Configuraçóes políticas e poderes locais, op. cit., p. 251.

${ }^{36}$ Ibidem, p. 253.

${ }^{37}$ SALVADOR, Frei Vicente. História do Brasil. São Paulo: Melhoramentos, 1975, p. 143.

${ }^{38}$ Idem.
} 
riormente de Caio Prado Junior, afirmando a hierarquia entre os governos ultramarinos e a supremacia do governador-geral do Estado do Brasil. Essa hierarquia entre esses poderes político-administrativos fundamenta-se na ordem corporativa e jurisdicional que caracteriza a monarquia portuguesa. Nesse sentido, numa sociedade com ordenação corporativa, a qualificação social, maior ou menor, dos que exercem cargos de mando, hierarquiza. Some-se a isso que, numa sociedade fundada no direito, ${ }^{39}$ as patentes e os regimentos organizam as funçôes e os poderes, assim como as hierarquias, indicando as instâncias e os espaços de autoridade e poder.

Como já analisamos em vários trabalhos, eram os governadores-gerais socialmente bem qualificados, fidalgos de origem, comendadores, conselheiros régios, alguns titulados, qualificação essa mais elevada que os governadores de capitania e, particularmente, os capitães-mores. ${ }^{40}$ Essas posiçôes hierárquicas muitas vezes não eram de todo formalizadas, mas se tornavam visíveis nas cerimônias e formas verbais e escritas utilizadas para a comunicação entre eles, como podemos constatar, por exemplo, na carta enviada pelo governador-geral, d. Vasco de Mascarenhas, conde de Óbidos, a Pedro de Mello, governador da capitania do Rio de Janeiro, onde, encaminhando informaçóes do Estado da Índia e do reino, afirma, ao término da correspondência de fevereiro de 1664, que dava "a V. Sa. esta notícia a toda a contingência, para que V. Sa. o tenha entendido, e de toda a que V. Sa. me der de seu serviço, farei com particular estimação". Os termos indicam a transmissão de ordens, mas também de relação entre indivíduos de uma mesma origem social — vossa senhoria ${ }^{41}$ — onde um fidalgo, que é conde, conselheiro régio e possui outras qualificaçóes sociais, se dirige a outro fidalgo, mas que é apenas comendador de São Pedro de Gouveia e de São Martinho de Pinhel, além de conselheiro de guerra. Ainda utilizando as formas de tratamento, tão representativas de hierarquia social no Antigo Regime, outro era o tratamento dispensado pelos governadores-gerais aos capitães-mores, provedores e ouvidores, ${ }^{42}$ todos chamados por vossa

\footnotetext{
${ }^{39}$ Ver a esse respeito as pertinentes e fundamentais explicaçôes de António Manuel Hespanha. Depois do Leviathan, op. cit., p. 10-12.

${ }^{40}$ Ver sobre os governadores gerais: COSENTINO, Francisco Carlos. Fidalgos portugueses no governo geral do Estado do Brasil, 1640-1702. Revista do Instituto Histórico e Geographico Brazileiro, v. 173, p. 15-43, 2012, e, COSENTINO, Francisco Carlos. Governadores-gerais do Estado do Brasil pós-Restauração: guerra e carreira militar. Varia História, Belo Horizonte, n. 48, 2012. Ver também CUNHA, Mafalda Soares da; MONTEIRO, Nuno Gonçalo. Governadores e capitães-mores do império atlântico português nos séculos XVII e XVIII. In: MONTEIRO, Nuno Gonçalo; CARDIM, Pedro; CUNHA, Mafalda Soares da (Orgs.). Optima Pars: elites ibero-americanas do Antigo Regime. Lisboa: ICS, 2005, p. 191-252.

41 "Senhoria. Em Portugal se fala aos Condes, \& a alguns Ministros" (BLUTEAU, D. Raphael. Vocabulario portuguez e latino. Rio de Janeiro: Universidade do Estado do Rio de Janeiro, s/d. CR-ROM, v. VII, p. 582). ${ }^{42}$ Um exemplo foi a carta de Afonso Furtado de setembro de 1672 ao capitão-mor Sebastiáo de Moura, da capitania de Porto Seguro, informando que escreveu à Câmara devido às "dúvidas" acontecidas na capitania entre o capitão-mor, o Ouvidor e a Câmara. O governador adverte "que se me chegar outra notícia de haver entre V. Mercê e eles a mínima diferença hei de castigar asperamente a quem for causa dela [...]". Conclui a carta dizendo que "como me foi presente que a pessoa que servia de Ouvidor teve bastante parte nessas dúvidas que houve e não procedeu como devia em suas obrigaçóes; mando Provisão daquele cargo [...] para que
} 
mercê, que, de acordo com Bluteau, era um "termo de cortesia que se usa em Portugal com qualquer pessoa honrada que não é titular". ${ }^{43} \mathrm{Ou}$ seja, no século XVII, entre os governadores ultramarinos, existia uma hierarquia social que tinha no governo-geral fidalgos mais qualificados socialmente que os governadores das capitanias do Rio de Janeiro e Pernambuco e, ainda mais, quando contrastados com os capitáes-mores que governavam as outras capitanias.

Entretanto, as hierarquias não se expressavam apenas por força dos rituais e etiquetas sociais do Antigo Regime. Ao lado disso, as cartas-patentes e os regimentos, de maneira explícita, ordenavam, atribuindo poderes distintos a governadores-gerais, governadores de capitania e capitães-mores. As cartas-patentes e os regimentos organizavam e diferenciavam o exercício do governo e, para compreendermos a vida política do Estado do Brasil, torna-se necessário compreendê-los e reconhecer que eles não existiam apenas como mera formalidade. ${ }^{44}$

Os governadores-gerais exerciam um ofício régio superior com funçôes delegadas de jurisdição inferior. Era um ofício de natureza superior por exercer alguns poderes próprios do ofício régio, e suas funçóes são de qualidade inferior, pois estas eram exercidas por delegação temporária e tinham suas decisóes submetidas, em última instância, ao monarca. Não vamos, no espaço deste artigo, explorar o exercício efetivo da ação de governo - a governação $\mathrm{o}^{45}$ propriamente dita — realizada pelos governadores-gerais, que pretendemos fazer em outros trabalhos, entretanto, entendemos a governação — o governar no Antigo Regime - como "uma esfera bem definida da política, da disputa política e da decisáo política". ${ }^{46}$ Esfera essa que podia "resumir-se aos seguintes tópicos: nomeação de pessoas para os cargos e ofícios superiores, remuneração de serviços (mercês), decisão final sobre contendas judiciais especialmente relevantes, política tributária e alinhamentos políticos externos (incluindo

juntamente sirva com o de Provedor com que se ficam evitando todas as ocasióes de se me repetir queixas e haver mais nessa capitania dúvida alguma" (Biblioteca Nacional do Rio de Janeiro, doravante denominada BNRJ, SM, 08, 03, 001, fl. 1).

${ }^{43}$ Bluteau, D. Raphael. Vocabulario portuguez e latino, op. cit., v. V, p. 431-432.

${ }^{44}$ COSENTINO, Francisco Carlos. Monarquia pluricontinental, o governo sinodal e os governadores-gerais do Estado do Brasil, op. cit., p. 67-82.

${ }^{45}$ Não temos um sentido próprio para governação nos dicionários do Antigo Regime. Em Covarrubias, governaçáo aparece como sinônimo de governar: "regir, encaminar y administrar, o la republica o personas y negócios particulares, su casa y su persona” (COVARRUBIAS, Sebastián de. Tesoro de la Lengua castellana o española (facsímil de 1943). Barcelona: Editorial Alta Fulla, 2003, p. 652). Em Bluteau temos o verbete governação associado a governar: "Mandar com supremo poder, \& autoridade. Governar hum Reyno, hum Imperio [...] Governar a Republica [...]" (BLUTEAU: s/d, v. IV, 103-104). Para Artola, governação é o "ejercicio del poder antes de su división en legislativo, ejecutivo y judicial", ou seja, "En la gobernación se confunden las funciones hasta el punto de que todas las autoridades participan de ellas, en particular de la jurisdicción". Concluindo que, "Cuando la Corona confiere jurisdicción a los políticos autoriza su iniciativa, e incluso la posibilidad de decidir sobre estas materias" (ARTOLA, Miguel. La Monarquía de España. Madri: Alianza Editorial, 1999, p. 23- 24).

${ }^{46}$ MONTEIRO, Nuno Gonçalo. D. Pedro II regente e rei (1668-1706). A consolidação da dinastia de Bragança. In: HESPANHA, António Manuel (Coord.). História de Portugal. O Antigo Regime. Lisboa: Editorial Estampa, 1998, v. 4, p. 410. 
guerra)". ${ }^{47}$ Reinterpretando e desdobrando essa compreensão aos governadores-gerais, observamos que, inclusive por força da regalia transferida a eles pelos monarcas quando da sua nomeação, esse ofício cimeiro provinha cargos, intervinha sobre contendas, ${ }^{48}$ geria as ações de guerra, ${ }^{49}$ atuava no sentido de que os tributos fossem pagos e coordenava a gestão financeira da administração das diversas capitanias sujeitas ao governo do Estado do Brasil, entre outras.

A criação do governo-geral em 1548 ocorreu quando já estavam instituídas as capitanias hereditárias ${ }^{50}$ cuja existência nas terras do Brasil implicara a concessão de jurisdição a particulares que, "efectivamente nunca contradisse em absoluto o exercício da suprema jurisdição do Monarca", ${ }^{1}$ determinando que o poder "dos capitães-donatários se exerceu em clara consonância e patente subordinação ao mando real". ${ }^{2}$ Assim sendo, pelas leis e pela vontade régia, as capitanias hereditárias foram enquadradas e submetidas quando da criação do governo-geral, a esses governantes maiores do Estado do Brasil.

Desde a nomeação de Tomé de Sousa que a monarquia portuguesa revogou os poderes concedidos aos donatários por meio das cartas-patentes dos governadores, orientação que teve continuidade durante a União Ibérica. Na patente de Tomé de Sousa o monarca informa aos "capitães e governadores das ditas terras do Brasil ou a quem seus carregos tiverem e aos oficiais da justiça e de minha fazenda em elas e aos moradores das ditas terras e a todos em geral e a cada hum em especial" ${ }^{3}$ que reconheçam Tomé de Sousa como "capitão da dita povoação e terras da Baya e governador geral da dita capitania e das outras capitanias e terras da dita costa" ${ }^{4} 4$ e que o "obedeção e cumprão e facão o que lhes o dito Thomé de Sousa de minha parte requerer e mandar segundo forma dos regimentos e provisóes minhas que pêra isso leva e lhe ao diante forem enviadas". ${ }^{5}$

\footnotetext{
${ }^{47}$ MONTEIRO, Nuno Gonçalo. D. Pedro II regente e rei (1668-1706), op. cit., p. 410-411.

${ }^{48}$ Ver o chamado conflito entre os Pires e Camargos na capitania de São Vicente/São Paulo que teve sua solução negociada pelo conde Atouguia e Francisco Barreto. Ver a esse respeito: Documentos Históricos da Biblioteca Nacional, doravante denominados DHBN, v. 3, p. 220-222; TAUNAY, Afonso D'Escragnolle. História da Cidade de São Paulo. São Paulo: Melhoramentos, 1953, p. 22-28, e FRANCO, Francisco de Assis Carvalho. Os capitães-mores vicentinos. Sáo Paulo: Separata da Revista do Arquivo, n. LXV, 1940, p. 81-84.

${ }^{49}$ Ver a esse respeito: ARAÚJO, Hugo André Flores Fernandes. Governação em tempo de guerra: Governo geral do Estado do Brasil e a gestão da defesa (1642-1654). Dissertação (mestrado) — Programa de Pós-Graduação em História. Universidade Federal de Juiz de Fora, 2014.

${ }^{50}$ COSENTINO, Francisco Carlos. Construindo o Estado do Brasil: instituições, poderes locais e poderes centrais. FRAGOSO, João; GOUVÊA, Maria de Fátima. O Brasil colonial, 1443-1580. v. I. Rio de Janeiro: Civilização Brasileira, 2014, p. 528-542.

${ }^{51}$ SALDANHA, António Vasconcelos de. As capitanias do Brasil. Antecedentes, desenvolvimento e extinção de um fenômeno atlântico. Lisboa: CNCDP, 2001, p. 364.

52 António Vasconcelos de Saldanha. As capitanias do Brasil, op. cit., p. 364.

${ }^{53}$ Arquivo Nacional da Torre do Tombo, doravante denominado ANTT — Chancelaria de D. João III, Livro 55, fl. $120 \mathrm{v}$.

${ }^{54}$ Idem.

${ }^{55}$ Idem.
} 
Até 1640 as cartas-patentes dos governadores mantiveram esses termos. Entretanto, deve ser ressaltada a argumentação empregada pelos reis para restringir os direitos delegados aos donatários. Utilizando cartas diferentes para apresentar essa situação, observamos que o monarca, depois de listar os poderes que detinham os donatários, explica que "muitas e justas causas e respeitos que me a isso movem o hei ora por bem de minha certa ciência por esta vez e nestes casos pera haver efeito todo o conteúdo na alçada regimentos e provisóes que [o governador] leva e ao diante lhe mandar", ${ }^{56}$ concluindo: "como de efeito hei por derrogadas as ditas doaçôes e todo o conteúdo nelas enquanto forem contra as cousas declaradas nesta carta e na dita alçada regimentos e provisóes". ${ }^{57}$ Em todas as patentes se repetia a capacidade régia de revogar os poderes concedidos recorrendo ao direito e às ordenaçôes que indicavam que se fizesse "expressa menção em especial derrogação às quais hei por expressas e declaradas como se de verbo ad verbum fossem nesta carta incorporadas sem embargo de quaisquer direitos leis e ordenaçôes que aja em contrário e da ordenaçáo do $2^{\circ}$ Lo $^{\circ}$ titto $44^{\prime \prime} .^{58}$

A carta patente do marquês de Montalvão (1640) ${ }^{59}$ não trouxe os argumentos apresentados pelas anteriores. A derrogação dos poderes concedidos aos donatários, presente até então, foi substituída por uma fórmula na qual todos estavam submetidos ao poder do governador-geral. ${ }^{60}$ Por toda a sua carta patente a fórmula utilizada é a de poder superior sobre todos no que diz respeito às questóes militares, de fazenda e de justiça, sem mençáo direta aos direitos desfrutados pelos donatários hereditários, como nas patentes dos governadores anteriores.

Esse foi o conteúdo seguido pelas cartas patentes posteriores à Restauração: reconhecendo a proeminência dos governos oriundos de nomeação régia e a crescente secundarização da autoridade governativa dos donatários hereditários. Esses foram o formato e o conteúdo da carta patente de António Teles da Silva, primeiro governador-geral enviado pelo governo

\footnotetext{
${ }^{56}$ Carta patente de Gaspar de Sousa (1612). ANTT - Chancelaria Felipe II, livro 29. O conteúdo e os termos usados nas cartas são praticamente os mesmos, por isso, vamos usar patentes diversas.

${ }^{57}$ Carta patente de Diogo de Mendonça Furtado. ANTT — Chancelaria Felipe III, livro 2, fl. 157v.

${ }^{58}$ Carta patente de Diogo de Mendonça Furtado. ANTT - Chancelaria Felipe III, livro 2, fl. 157v. A lei que consta da Ordenação, "diz que se não entenda ser pro mim derogada ordenaçáo algua se da sustancia della se não fizer expressa menção e declaração". Ver Ordenaçoens do Senhor Rey D. Manuel. Coimbra: Real Imprensa da Universidade, 1797, livro II, p. 242; e Código Philippino. Tomo II. Rio de Janeiro: Typographia do Instituto Philomathico, 1870, p. 467.

${ }^{59}$ ANTT. Chancelaria Felipe III, livro 28, fl. 297.

${ }^{60}$ Montalvăo foi enviado como vice-rei e tem-se dito que trouxe esse título para negociar em igualdade com Maurício de Nassau. Acreditamos que os Felipes pretendiam instituir o vice-reinado no Estado do Brasil. Sua carta patente - "e tudo o que por ele de minha parte vos for mandado cumprais e façais intramente com aquella diligencia e cuidado que de vos confio como fizereis se por mim em pessoa vos fosse mandado" (ANTT - Chancelaria Felipe III, livro 28, fl. 297) - utilizava a mesma fórmula empregada para os vice-reinados espanhóis: "nossa Real pessoa" (Recopilacion de Leyes de los Reynos de las Índias. Tomo I, libro III, tit. II. Madri: INBOE, 1998, p. 543). Os mesmos termos da patente de Montalvão estáo na patente do conde de Óbidos: "como o fizeres se por mim em pessoa vos fora mandado" (BNRJ - SM. 1, 2, 5). Óbidos veio como vice-rei, pois, como havia sido no Estado da Índia, não poderia vir com um cargo menor conforme a hierarquia social dessa época.
} 
bragantino, onde estava dito que ele podia usar da "jurisdição, alçada, poderes, proeminências, liberdades \& prerrogativas que lhe tocam \& que tiveram \& que usaram os outros governadores do dito Estado do Brasil seus antecessores". ${ }^{61}$ Em seguida, depois de afirmar que o governador poderá "usar dos mesmos regimentos \& provisôes de q' eles usaram [os outros governadores] e dos mais q eu lhe mandar dar" ${ }^{62}$ indica que "todos capitães $\&$ governador das capitanias do dito Estado \& aos mestres de campo sargentos mores Capitães de infantaria soldados \& gente de guerra oficiais de justiça e de minha fazenda q' hora nele me estão servindo \& ao diante servirem" ${ }^{33}$ devem obediência ao governador-geral e "cumpram $\&$ guardem inteiramente seus mandados \& ordens como devem \& são obrigados" ${ }^{64}$

Concluindo, as cartas patentes do governo-geral do Estado do Brasil, ao longo do século XVII, indicam que os donatários hereditários não eram mais figuras proeminentes na ação de governo das capitanias ou os seus loco-tenentes, mesmo que esses senhorios continuassem a existir e os seus donatários, algumas vezes, interferiam no provimento de ofícios, inclusive de capitão-mor, e recebessem seus rendimentos. ${ }^{65}$ Todas as cartas patentes afirmam a supremacia da autoridade dos governadores-gerais sobre todos os outros servidores providos ou não pela monarquia portuguesa no Estado do Brasil, exceto a de Roque da Costa Barreto, igual em conteúdo, mas, com forma diferente, retornando o formato com António de Sousa de Meneses, seu sucessor, e os que o seguiram no século XVII. A patente de Roque da Costa Barreto, por ter ele trazido o novo regimento para o governo-geral, utilizado até 1808 , frisava que ele não era enviado com a mesma autoridade e jurisdição dos governadores e capitães-gerais, mas tinha mais, por isso, eles "lhe obedecerão e guardarão suas ordens assim no militar como no civil e político", assim como "os ministros e oficiais de justiça guerra e fazenda, chanceler, desembargadores, e governadores do Rio de Janeiro, e Pernambuco e das mais capitanias subordinadas ao governador-geral tudo na forma de meus regimentos" ${ }^{66}$

\footnotetext{
${ }^{61}$ ANTT - Chancelaria de D. João IV, livro 10, 354v.

${ }^{62}$ ANTT - Chancelaria de D. João IV, livro 10, 354v. O conteúdo das cartas dos governadores que o sucederam é o mesmo até Roque da Costa Barreto. Esse governador trouxe um novo regimento, empregado até 1808, e a forma e conteúdo da sua carta patente é diferente, como veremos a seguir. Sobre esse regimento ver: COSENTINO, Francisco Carlos. Governadores gerais do Estado do Brasil (séculos XVI-XVII): ofício, regimentos, governação e trajetórias. São Paulo: Annablume/FAPEMIG, 2009, p. 245-303.

${ }^{63}$ Carta patente de António Teles de Meneses. BNRJ - SM. 1, 2, 5. Estou mesclando trechos de cartas de governadores diferentes para demonstrar ser o conteúdo absolutamente o mesmo.

${ }^{64}$ Carta patente de D. Jerônimo de Ataíde. ANTT — Chancelaria de D. João IV, Livro 26, fl. 23.

${ }^{65} \mathrm{~A}$ monarquia portuguesa assumiu algumas capitanias hereditárias passando a considerá-las como reais. Os diversos donatários iniciaram uma longa pendenga judicial com a monarquia e tiveram seus direitos reconhecidos, obrigando a monarquia portuguesa a indenizá-los de formas diversas até o período pombalino que aboliu esses senhorios. Ver António Vasconcelos de Saldanha, op. cit., p. 134-138 e 387-435.

${ }^{66}$ ANTT - Registro Geral das Mercês. Chancelaria de Afonso VI, livro 29, fl.116v-117.
} 
Dessa forma, a tendência manifestada desde o período filipino de marginalizar das tarefas governativas os donatários das capitanias do Estado do Brasil se aprofundou com os primeiros monarcas bragantinos nas cartas patentes emitidas e ganhou forma mais elaborada com os regimentos elaborados ao longo dos Seiscentos. Foram regimentos produzidos para ordenar os governos ultramarinos. Reproduziram a subordinação ao governo-geral das capitanias principais e das anexas, das capitanias reais e das de donatário, num esforço organizador realizado pela monarquia portuguesa e seus oficiais maiores no Estado do Brasil. Foram esses regimentos: o dos capitáes-mores elaborado no governo do conde de Óbidos (1663); e, aqueles elaborados pela monarquia bragantina para o governo-geral (o regimento de Roque da Costa Barreto, 1677), e para o governo das capitanias principais (capitania de Pernambuco, 1670; capitania do Rio de Janeiro, 1679).

No governo do vice-rei d. Vasco de Mascarenhas, conde de Óbidos, foi feito o "Regimento que se mandou aos Capitães-mores das Capitanias deste Estado" ${ }^{67}$ porque eram "grandes os inconvenientes que resultam de os Capitães-mores das Capitanias deste Estado não terem Regimento que sigam" ${ }^{68}$ A submissão das capitanias, fossem elas reais ou de donatários, e a autoridade do governador-geral estão presentes em várias passagens e, explicitamente no seu parágrafo 3ำ, encontramos: "Terá o Capitão-mor entendido que nenhuma Capitania das do Estado, ou seja Del-Rei meu Sr ou Donatario é subordinada ao Governo de outra Capitania de que seja vizinha: e todas são imediatas e sujeitas a este geral: por cujo respeito só dele há de aceitar o Capitáo-mor as ordens". ${ }^{69}$

Por sua vez, os regimentos do governo-geral, desde o primeiro, o de Tomé de Sousa, estabeleceram a supremacia do governo-geral e a submissão dos governos das capitanias. Essa supremacia pode ser percebida na instrução que dizia que, se "algum Capitão das Capitanias daquelle Estado cometa alguma força violencia, ou extorsão publica e notória" ${ }^{70}$ deve o governador-geral prover "logo na governança e guarda das Capitanias pessoas de confiança enquanto assim estiverem suspensos os capitaens e me avisareis de tudo o que nisto se fizer". ${ }^{71}$ Era explícita a orientação para que o governador-geral controlasse a jurisdição dos donatários, preocupaçáo que ganhou forma no regimento de Gaspar de Sousa e se repetiu, com pequenas alteraçôes, até o Regimento de Roque da Costa Barreto. No de Diogo de Mendonça Furtado instruía:

Assim como convém a meo serviço não deixardes de tomardes Donatários mais jurisdição da que lhe pertencer por suas doaçoens e terdes nella muita vigilância e advertencia assim mesmo

\footnotetext{
${ }^{67}$ DHBN, v. V, p. 374

${ }^{68}$ Idem.

${ }^{69}$ Ibidem, p. 375-376.

${ }^{70}$ Regimento de Diogo de Mendonça Furtado (1621). Arquivo Público do estado da Bahia (APEB), S.C., estante 1, caixa 146, livro 264, fl. 106.

${ }^{71}$ Idem.
} 
hei por bem que vos não tomeis a sua nem consintaes que os meos Officiaes de Justiça lhe tomem nem quebrem seos privilegios e doaçoens antes em tudo o que lhe pertencer lhe fareis cumprir e guardar. ${ }^{72}$

O regimento de Roque da Costa Barreto (1677), síntese dos regimentos anteriores, empregado para ordenar o governo-geral e os vice-reinados até 1808, apresentava, quanto aos donatários, capítulos com conteúdo semelhante. Esse foi um momento no qual a ordem política administrativa se tornou mais complexa, com um maior número de capitanias e, entre elas, a proeminência das capitanias de Pernambuco e do Rio de Janeiro. Era necessário ordenar e esse regimento definiu o relacionamento do governo-geral com as diversas capitanias. Conforme era estilo da prática jurisdicional da época, o regimento de Roque da Costa Barreto incorporou os regimentos dos capitães-mores e dos governadores de capitanias (Rio de Janeiro e Pernambuco) e isso pode ser constatado na passagem que indicava, conforme "o disposto nos mais Regimentos dos Governadores e Capitães-Mores seus subordinados". 73

Quanto aos donatários, esse regimento aborda sua submissão com um formato mais preciso e adequado a uma conquista ultramarina que cresceu, tornou-se mais complexa e caminhava para se tornar a principal parte da monarquia pluricontinental portuguesa. Por isso, assim era tratada essa questão:

Assim como convém a meu serviço não deixar tomar aos Donatários mais jurisdição que a que lhes pertence, por supor suas doaçóes, e ter-se nela muita vigilância e advertência, assim mesmo, hei por bem que o Governador lhes não tome a sua, nem consinta que os Ministros da Justiça, Fazenda, e Guerra, lh’a tomem, nem quebrem seus privilégios, nem doaçôes, antes em tudo, o que lhes pertencer, fará o dito Governador cumprir e guardar; porém, terá entendido que mandará observar inviolavelmente o que se dispóe no capítulo 25ำ deste Regimento sobre a jurisdição dos Donatários e forma em que devem ser providas suas Capitanias. ${ }^{74}$

A instrução refinou a orientação para manutenção dos espaços próprios da jurisdição dos donatários e governadores das capitanias, preservando a jurisdição real. Ressaltou o controle do governador sobre os oficiais da Fazenda, da Justiça e da Guerra, como também demarcou certos poderes dos governantes das capitanias. Na prática o regimento de 1677 reconheceu as particularidades existentes entre as capitanias principais e as anexas e estabeleceu, na hierarquia de autoridade entre as capitanias, que as principais de Pernambuco e do Rio de Janeiro podiam prover a serventia de ofícios por um tempo: “de Pernambuco por

\footnotetext{
${ }^{72}$ Ibidem, fl. 108.

${ }^{73}$ MENDONÇA, Marcos Carneiro de. Raizes da formação Administrativa do Brasil. Rio de Janeiro: IHGB/ Conselho Federal de Cultura, 1972, p. 753.

${ }^{74}$ Ibidem, p. 802.
} 
três meses somente, e o do Rio de Janeiro por seis". 75 Por sua vez, era o regimento explícito quanto à autoridade dos governadores-gerais sobre os governadores das capitanias principais do Rio de Janeiro e Pernambuco e estabelecia que "os ditos governadores são subordinados ao Governador-geral, e que hão-de-obedecer a todas as ordens que ele lhes mandar, dando-lhe o cumpra-se, e executando-as", da mesma forma que "aos mais Ministros de Justiça, Guerra, ou Fazenda". ${ }^{76}$

$\mathrm{O}$ que estava indicado no regimento dos capitães-mores e do governo-geral quanto à subordinação dos governos das capitanias do Estado do Brasil, também estava registrado no regimento do governador de Pernambuco (Fernão de Sousa Coutinho, 1670) ${ }^{77}$ e no do Rio de Janeiro (Manuel Lobo, 1679). ${ }^{78}$ Utilizando como exemplo o regimento do governador da capitania do Rio de Janeiro, com a exceção já assinalada anteriormente a respeito do provimento de ofícios, que o governador dessa capitania poderia fazer por seis meses para "não parar o curso dos negócios pertencentes à Justiça e Fazenda" , ${ }^{79}$ deveria o governador da capitania dar "conta ao Governador-geral do Estado, tanto que vagarem, e provendo ele os tais ofícios nas pessoas que vos apresentarem os tais Provimentos, lhes poreis o cumpra-se". ${ }^{80}$ Deveria também o governador do Rio de Janeiro, segundo seu regimento, enviar “informação dos sujeitos beneméritos que houver no [...] governo, para que sendo tudo presente ao Governador, me proponha três pessoas que lhe parecer, para o dito posto" ${ }^{81}$ de guerra, além de, quando sucediam "algumas cousas que por este Regimento não vão providas e cumprir fazer-se nele obra", ${ }^{82}$ deveria dar conta do que foi feito ao governador-geral e ao monarca.

Essa dinâmica foi reafirmada na carta enviada pelo governador-geral Roque da Costa Barreto ao governador do Rio de Janeiro Pedro Gomes, em novembro de 1681. Apoiado na posição de desembargadores da Relação, Barreto argumentava com Pedro Gomes, depois de lembrá-lo do parágrafo 18 do regimento da capitania do Rio de Janeiro, que "as provisóes do governo-geral se devem contar depois dos ditos seis meses acabados porque foram concedidos ao governo do Rio de Janeiro especialmente e sempre se lhes deviam fazer

\footnotetext{
75 Ibidem, p. 803.

${ }^{76}$ Ibidem, p. 804.

${ }^{77}$ RAU, Virgínia, SILVA, Maria Fernanda Gomes da. Os manuscritos do Arquivo da Casa de Cadaval respeitantes ao Brasil. v. I. Coimbra: Acta Universitatis Conimbrigensis, 1955, p. 200-207.

${ }^{78}$ Marcos Carneiro de Mendonça. Raízes da formação administrativa do Brasil, op. cit., p. 901-910. Quanto ao regimento do governo da capitania de Pernambuco seguimos as afirmaçóes de Veríssimo Serráo que o regimento dado ao governador do Rio de Janeiro, Manuel Lobo, em 1679 foi elaborado com as mesmas preocupaçôes ordenadoras e perenes que nortearam o regimento de Barreto, assim como o regimento dos governadores de Pernambuco (SERRÃO, Joaquim Veríssimo. História de Portugal. A Restauração e a Monarquia Absoluta (1640-1750). 2. ed. Lisboa: Editorial Verbo, 1982, v. V).

79 Ibidem, p. 905.

${ }^{80}$ Idem.

${ }^{81}$ Idem.

${ }^{82}$ Ibidem, p. 908.
} 
completos" ${ }^{83}$ e que só depois desses dezoito meses o provido podia ser removido. Roque da Costa Barreto complementa ainda afirmando que o "mesmo se pratica na capitania de Pernambuco onde aquele governo prove por três meses e o governo-geral por hum ano que se principia depois dos três meses acabados com que cada provido fica servindo quinze meses em Pernambuco". ${ }^{84}$ Estamos tratando aqui de provimento de serventia de ofício, já que a concessão da propriedade de um ofício era prerrogativa régia, muitas vezes exercida e capaz de preencher os diversos cargos que a vida administrativa da conquista exigia. No entanto, a dinâmica administrativa regularmente deixava vagos muitos dos cargos essenciais para a gestão do território ultramarino, fazendo com que a atuação dos governos ultramarinos no provimento da serventia dos diversos ofícios da administraçáo fosse recorrente.

Exemplificamos com o ofício de provedor da Fazenda Real da capitania do Rio de Janeiro quando era proprietário Pedro de Souza Pereira. Com seu falecimento, o governador-geral Afonso Furtado de Mendonça, em 19 de novembro de 1672, prove o capitáo José de Barcellos Machado "da serventia do dito cargo por tempo de um ano enquanto Sua Alteza o houver assim por bem, ou eu não ordenar outra cousa" ${ }^{85}$ Dois anos depois, d. Pedro, devido a mercê feita por $\mathrm{d}$. João IV, transmitiu o ofício para o filho do antigo proprietário e, pela carta patente de 3 de fevereiro de 1674, faz o provimento da propriedade do ofício de provedor do Rio de Janeiro em Thomé de Souza Corrêa. ${ }^{86}$

Em 1680, as regras que ordenavam o provimento dos cargos transparecem quando Roque da Costa Barreto, em outubro, provê a serventia do ofício em João da Rocha Pitta por "estar vago o cargo de Provedor da Fazenda Real da Capitania do Rio de Janeiro por falecimento da pessoa que o servia por Provisão do Senhor Dom Manuel Lobo na falta de seu Proprietário". ${ }^{87}$ De acordo com a nomeação realizada pelo governador-geral ela se fazia seguindo a "ordem de Sua Alteza que quando vagar o cargo de Provedor-mor da Fazenda do dito Estado se encarregue a ocupação dele a um Ministro, e útil a seu Real serviço que o mesmo se pratique naquela Capitania" ${ }^{\prime 8}$ e a serventia, conforme já assinalamos anteriormente, se fazia pelo "tempo de um ano enquanto Sua Alteza o houver assim por bem, ou eu não ordenar outra cousa" ${ }^{89}$ Foi o que acabou acontecendo. Dois meses antes do provimento do governador-geral, d. Pedro, devido ao "impedimento de [...] Thomé de Souza Corrêa Proprietário dele e de presente estar [ele] [...] notificado para vir a este Reino", ${ }^{90}$ o príncipe regente reconduz Pedro de Souza Pereira, irmão do proprietário do ofício de provedor da

\footnotetext{
${ }^{83}$ ANRJ, códice 61, v. 07, fl. 478.

${ }^{84}$ ANRJ, códice 61, v. 07, fl. 479v.

${ }^{85}$ DHBN, v. 25, p. 157.

${ }^{86}$ DHBN, v. 26, p. 91.

${ }^{87}$ DHBN, v. 27, p. 323.

${ }^{88}$ DHBN, v. 27, p. 323.

${ }^{89}$ DHBN, v. 27, p. 325.

${ }^{90}$ DHBN, v. 27, p. 358.
} 
Fazenda da capitania do Rio de Janeiro, ao cargo por mais dois anos "se tanto durar o impedimento do [...] Proprietário seu Irmão Thomé de Souza Corrêa". ${ }^{91}$

Ressalte-se que, como assunto de importância na governaçáo, o provimento de ofícios seguia os trâmites do direito praticado nos regimentos e articulava-se com iniciativas negociadoras dos governadores-gerais que demonstram que esses oficiais maiores tinham sensibilidade para perceber as alianças locais, com suas clientelas e relaçôes com os governadores locais.

Assim, os governadores-gerais abriam espaço para indicaçôes, como a de Afonso Furtado de Mendonça (1671-1675), que, em longa carta para Fernão de Sousa Coutinho, governador da capitania de Pernambuco, depois de admoestá-lo e argumentar sobre Itamaracá não ser anexa ao seu governo, mesmo assim afirma que proverá "os ofícios políticos nas pessoas da memória de Vossa Senhoria. E sem embargo desta suspensão sempre proverei nela as mais que Vossa Senhoria levar gosto, crendo de mim que nada pretendo mais que dá-lo a Vossa Senhoria". 92

E também negociavam o cumprimento do estabelecido nos regimentos, como o que fez Alexandre de Sousa Freire (1663-1667) diante do provimento de João Correa de Faria como ouvidor-geral feito pelo governador da capitania do Rio de Janeiro, d. Pedro Mascarenhas. Sousa Freire indica ao governador da capitania que a nomeaçáo feita por ele "tem alguns inconvenientes, que dificultam confirmá-lo com provisão minha", porém, contornando a questáo, indica que "para que nem eu falte em dar gosto a V. Sa., nem V. Sa. à segurança que deste meu animo pode ter", ${ }^{93}$ permite que Faria — que estava provido como capitão-mor de São Vicente - permanecesse no cargo até que a nomeação régia se efetivasse, o que ocorreu em seguida. ${ }^{94}$

Em síntese, as cartas patentes e os regimentos, nos vários contextos em que foram elaborados, estabeleciam a supremacia do poder dos governadores-gerais sobre os governadores das capitanias e dos donatários, particularmente durante os séculos XVI e XVII, ${ }^{95}$ ao contrário do que a historiografia brasileira tem afirmado.

\footnotetext{
${ }^{91}$ DHBN, v. 27, p. 358.

${ }^{92}$ DHBN, v. 10, p. 18.

${ }^{93}$ DHBN, v. VI, p. 91.

${ }^{94}$ Segundo Franco, João Correa de Faria foi provido capitão-mor de São Vicente por indicação do donatário da capitania, não se tendo registro de sua posse. Por outro lado, o mesmo autor indica que empossado no "cargo de ouvidor-geral da repartição sul, que chegou a exercer algum tempo", perdeu a função "porque o governador-geral do Brasil, Alexandre de Sousa Freire, anulou a nomeação, pelo fato de não terem os capitães-mores competência para tanto" (Francisco de Assis Carvalho Franco. Os capitáes-mores vicentinos, op. cit., p. 87).

${ }_{95}$ Os governadores enviados ao Estado do Brasil no século XVIII, na maioria com o título de vice-reis, não são objeto desse estudo, entretanto, tinham pelas suas cartas patentes e regimento, o de 1677, os mesmos poderes que os governadores-gerais que os antecederam. Essa constatação reforça o questionamento sobre as conclusóes dos que afirmam que governos ultramarinos, sem distinção, tinham os mesmos poderes.
} 


\section{Capitanias régias, hereditárias, principais e anexas; governadores e capitáes-mores}

O relacionamento entre o governo-geral e os governos das capitanias do Estado do Brasil é um tema pouco frequentado pela historiografia e, por isso, apresenta um conjunto de lacunas a respeito do estatuto das diversas capitanias dessa parte do ultramar. É sobre essas lacunas que pretendemos tratar a seguir, caracterizando as capitanias hereditárias e régias, as capitanias principais e anexas e as relaçôes entre elas.

Quanto às capitanias hereditárias, as suas transformaçóes, a identificação da sua natureza senhorial e o seu desenvolvimento, inclusive sua extinção, está bem apresentado no trabalho de António Vasconcelos de Saldanha. Entretanto, existem outros aspectos que cercam a vida das capitanias que precisam de tratamento histórico, inclusive com uma abordagem que incorpore percepçóes originárias do desenvolvimento da pesquisa contemporânea, já que as análises elaboradas algumas décadas atrás se mostram limitadas diante dos progressos da pesquisa histórica, ${ }^{96}$ como o trabalho de Saldanha.

Criadas como hereditárias, senhorios doados pelos monarcas para realização inicial da atividade de povoamento e colonização, poucas capitanias foram ocupadas pelos seus donatários e, com isso, continuaram hereditárias. ${ }^{97}$ Após 1640 , outras capitanias hereditárias foram criadas, como a de Cabo Frio e da Paraíba do Sul/Campos dos Goitacazes. Após a Restauração, as capitanias que continuaram hereditárias passaram a desfrutar de estatutos diversos. Algumas tiveram sua condição de senhorios mantidos, enquanto outras, como a capitania de Pernambuco, passaram unilateralmente para controle régio, sob o argumento de terem sido retomadas aos estrangeiros invasores pelo monarca e pelos seus vassalos. ${ }^{98}$

\footnotetext{
${ }^{96}$ Esse é o caso da caracterização como feudal: "Em suma, convicto da necessidade desta organização feudal, D. João III [...]” (ABREU, Capistrano. Capitulos de História colonial. São Paulo: Publifolha, 2000, p. 67) ou "de engenho imaginativo do capitalismo régio português" (DIAS, Manuel Nunes. O sistema das capitanias do Brasil. Boletim da Biblioteca da Universidade de Coimbra, volume XXXIV, 3. parte, 1980).

${ }^{97}$ Ver a esse respeito Francisco Carlos Cosentino. Construindo o Estado do Brasil: instituiçóes, poderes locais e poderes centrais, op. cit., p. 521-586.

${ }^{98}$ As capitanias que tiveram seu estatuto hereditário ignorado, como Pernambuco, seus donatários e herdeiros sustentaram açôes na justiça contra o monarca visando recuperar seus direitos. Nos argumentos expostos na representação feita pelos condes do Vimioso, donatários de Pernambuco, contra a monarquia, alguns dos argumentos utilizados em favor dos seus direitos pela capitania. Listando dez argumentos, o documento diz, em alguns, que "[...] Em o sexto, que o Principe he obrigado a observar a dita Doaçam, como nelle se contem, e não só a não pode alterar, mas a deve mandar cumprir não só pela rezam da justiça, conveniencia publica, rezão de estado, mas pela obrigaçam da promessa, e concessam, que obriga nam só ao Snôr Rey, que a fez; mas a todos seus successores. Em o Septimo, q' os Senhores Condes Authores são verdadeiros successores destes bens, e Capitania, ainda que a Sra Condeça seja femea. Em o Octavo, que o Principe he obrigado a mandar restituir estes bens a os Senhores Condes Authores, ainda que os recuperasse do inimigo Olandes" (Biblioteca Nacional de Lisboa, BNL — FG 1034. Allegaçam de dereito por parte dos senhores condes do Vimiozo sobre a svccessam da capitania de Pernambvco.... Officina da Universidade, Évora, 1671, fl. 5).
} 
A existência desses senhorios, como dito anteriormente, não excluía seus donatários da subordinaçáo ao poder dos monarcas, consoante os princípios do direito em vigor no Portugal do Antigo Regime. ${ }^{99}$ Com o governo-geral, a Coroa interviu na vida interna das capitanias, "seja na sua faceta política, como na económica ou jurisdicional em termos que não admitem dúvidas quanto a limitação profunda que sofreu a ação dos donatários". 100 Tornaram-se essas capitanias um senhorio de "contentamento do Donatário", ${ }^{101}$ conforme a posiçấo do procurador da Coroa a respeito dos direitos dos marqueses de Cascais sobre a capitania de Itamaracá, e que repercutiu nas incorporaçôes das outras donatarias do Estado do Brasil. Eram terras que propiciavam "renda por sua doação e pelo estado da terra, acrescentando-se também o que podia valer o jurisdicional e honorífico". ${ }^{102}$ Com a Restauração, passamos a ter aquilo que Felisbello Freire chamou de "transformação do regime das donatarias em capitanias políticas". ${ }^{103} \mathrm{Ou}$ seja, permaneceram as capitanias como senhorios de seus donatários, governadas e administradas, porém, por provimento régio, com capitães-mores indicados pelos donatários em lista tríplice para escolha régia, e, na ausência da manifestação senhorial e confirmação régia, os provimentos eram feitos pelos governadores-gerais.

Os territórios que não foram ocupados pelos seus donatários, inclusive a Bahia, adquirida aos herdeiros do donatário quando da criação do governo-geral, tornaram-se capitanias régias. Esses eram os territórios onde os objetivos "que presidiram aos actos régios constitutivos das capitanias: distribuição da terra, colonização, propagação da fé", ${ }^{104}$ não foram realizados pelos seus donatários, mas pela iniciativa dos monarcas e seus representantes.

Nas capitanias de donatários ou nas do monarca, o provimento dos diversos ofícios e para os governos - governadores para Pernambuco e Rio de Janeiro e capitáes-mores para as restantes - eram feitos pelo rei, de acordo com as Ordenaçóes do reino e como produto dos poderes advindos da regalia. ${ }^{105}$ Os governadores das capitanias foram sempre nomeados pelo rei, e os capitáes-mores, majoritariamente nomeados pelo monarca. Como ofícios de governo, os capitães-mores exerciam um cargo hierarquicamente cimeiro na sua capitania

\footnotetext{
99 “[...] foram dezoito as donatarias aqui instituídas no século XVI e apenas quatro as da Coroa. No século XVII criaram-se doze donatárias nos Estados do Brasil e do Maranhão (seis em cada um), e apenas mais cinco Capitanias reais" (VIANA, Hélio. Liquidação das donatarias. Revista do IHGB, v. 273, p. 148, out./ dez. 1966).

${ }^{100}$ António Vasconcelos de Saldanha. As capitanias do Brasil, op. cit., p. 365.

${ }^{101}$ Ibidem, p. 409.

${ }^{102}$ Idem.

${ }^{103}$ FREIRE, Felisbello. História territorial do Brazil. 1. v. (Bahia, Sergipe e Espírito Santo). Salvador: Secretaria da Cultura e Turismo/Instituto Geográfico e Histórico da Bahia, 1998, p. 10.

${ }^{104}$ António Vasconcelos de Saldanha. As capitanias do Brasil, op. cit., p. 364.

${ }^{105}$ Ver Código Filipino ou Ordenaçóes e Leis do Reino de Portugal, Segundo Livro, Título XXVI, Dos Direito Reais. Brasília: Ediçóes do Senado, 2004, p. 440-443. De acordo com Bluteau, a palavra Rei, "quando se refere a dignidade Real, denota jurisdiçáo sobre todos os que vivem no seu reyno" (BLUTEAU, D. Raphael. Vocabulario Portuguez e Latino, op. cit., vol. VII, p. 208), inclusive quanto ao provimento dos ofícios, inclusive os mais elevados, como eram o de governador das partes ultramarinas.
} 
e detinham poderes de governo que os sujeitavam ao pleito $\&$ menagem, ${ }^{106}$ por isso, na sua grande maioria, eram providos pelo monarca. Entretanto, na sua ausência, podiam os governadores-gerais emitir carta patente para esse ofício até que a nomeação régia acontecesse.

Nas capitanias de donatário, os capitães-mores eram nomeados pelo monarca a partir de lista tríplice apresentada pelo donatário, prática que foi seguida até a extinção das donatarias no século XVIII. O provimento de capitães-mores para a capitania de São Vicente, donataria dos marqueses de Cascais, exemplifica os procedimentos de provimento desse ofício. Em 28 de maio de 1656, em razão da morte do capitão-mor Gonçalo Couraça de Mesquita, d. Jerônimo de Ataíde, conde de Autoguia, nomeia Miguel Quavedo de Vasconcelos "para que como tal o seja, use, e exerça [o cargo de capitão-mor] enquanto Sua Majestade o houver assim por bem, ou eu não mandar outra cousa" 107 com todas "as honras, jurisdição, graças, franquezas, privilégios, preeminências, isençóes, e liberdades que lhe tocam, podem e devem tocar a todos os Capitães-mores das Capitanias deste Estado, e de que gozou o dito seu antecessor”. ${ }^{108}$ Em 23 de novembro de 1656, a rainha regente, por sugestáo do donatário da capitania, prove Manuel Sousa da Silva como capitão-mor. ${ }^{109}$ Dois anos depois, em outubro de 1658, o governador Francisco Barreto de Meneses emitiu carta patente para Jerônimo Pantoja Leitão para que ele pudesse "suceder no Governo da mesma Capitania em caso que o referido Capitão-mor faltasse", ${ }^{110}$ enquanto "Sua Majestade o houver assim por bem, ou eu não ordenar outra cousa, para que como tal o seja, use, e exerça com todas as honras, graças, jurisdição, poder e mais preeminências". ${ }^{111}$ Em 12 de dezembro de 1658, d. Luísa de Gusmão, rainha regente, atendendo a indicação em lista tríplice para o governa da capitania de São Vicente, escolheu Manuel de Almeida Falcão. ${ }^{112}$

Essa sequência esclarece os procedimentos para a nomeação dos capitães-mores para as capitanias de donatários. Nomeação régia por três anos, por indicação de lista tríplice apresentada pelo donatário ${ }^{113}$ e, na falta de nomeação feita pelo rei, provimento feito pelo

${ }^{106}$ Sobre essa cerimônia essencial no provimento dos cargos detentores de poder no Portugal do Antigo Regime ver: COSENTINO, Francisco Carlos. O ofício e as cerimônias de nomeação e posse para o governo-geral do Estado do Brasil (séculos XVI e XVII). In: BICALHO, Maria Fernanda; FERLINI, Vera Lúcia Amaral (Org.). Modos de governar. Ideias e práticas políticas no império português. Séculos XVI a XIX. São Paulo: Alameda, 2005, p. 137-155.

${ }^{107}$ DHBN, v. 31, p. 189-190.

${ }^{108}$ DHBN, v. 31, p. 189-190.

${ }^{109}$ AHU - Consultas Mistas, Códice 15, fl. 257v.

${ }^{110}$ DHBN, v. 31, p. 237-238.

${ }^{111}$ DHBN, v. 31, p. 237-238.

${ }^{112}$ AHU - Consultas Mistas, Códice 15, fl. 304v.

${ }^{113}$ Esse é o caso do provimento feito por d. Afonso VI de João Corrêa de Faria, em outubro de 1667, para capitão-mor de São Vicente conforme a indicação do marquês de Cascais, que propôs "para Capitão dela três pessoas na forma de minhas ordens para eu escolher, e nomear a que for servido". A nomeação régia valia "pelo tempo de três anos assim e da maneira que a serviram os mais Capitães seus antecessores na forma das doaçôes do dito donatário", com todos os "proes e percalços que diretamente lhe pertencerem, e gosará de todas as honras, privilégios, isençóes preeminências, franquezas, e liberdades que em razão do dito cargo lhe tocarem" (DHBN, v. 23, p. 176). 
governador-geral que, pelo caráter provisório da medida, estabelecia como prazos até que uma nomeação fosse feita pelo monarca, ${ }^{114}$ ou entâo, por nova escolha do governador-geral.

$\mathrm{Na}$ América lusa as capitanias eram hierarquizadas em principais e subalternas ou anexas. Caio Prado Junior, um dos poucos a tratar disso, ${ }^{115}$ afirmou:

As capitanias que formavam o Brasil são de duas ordens: principais e subalternas. Estas são mais ou menos sujeitas àquelas; muito, como as do Rio Grande do Sul e Santa Catarina ao Rio de Janeiro, ou a do Rio Negro ao Pará; pouco, como a do Ceará e outras subalternas de Pernambuco. ${ }^{116}$

No Estado do Brasil durante o século XVII tínhamos três capitanias principais, Pernambuco, Bahia e Rio de Janeiro, que eram os territórios de colonização e povoamento mais antigos e de maior desenvolvimento econômico, político e cultural. O restante das capitanias, fossem elas régias ou de donatários, eram anexas a essas capitanias principais, conforme indicado no quadro a seguir. ${ }^{117}$

\footnotetext{
${ }^{114} \mathrm{Na}$ mesma patente citada na nota anterior, o provimento régio indicava que “à pessoa que estiver servindo de Capitão da dita Capitania, e em sua falta, aos oficiais da Câmara dela lhe dem a posse da mesma Capitania, e lhe deixem servir na forma referida" (DHBN, v. 23, p. 177). O que significa dizer que o provimento régio anulava qualquer outro feito anteriormente.

${ }^{115}$ Encontradas na documentaçáo, Caio Prado Junior afirma sua existência e diferença, sem entrar em detalhes. O trabalho de António Vasconcelos de Saldanha sobre as capitanias não abordou essa questão.

${ }^{116}$ Caio Prado Junior. Formação do Brasil Contemporâneo, op. cit., p. 305-306. O autor trata de Brasil como se apenas essa unidade política existisse - conforme percepção de cunho nacionalista vigente no seu tempo ignorando as particularidades existentes entre o Estado do Brasil e do Estado do Maranhão, da mesma forma que outros autores. Entretanto, apesar de incompletas, eles nos servem como uma referência. Esse é o caso do trabalho de Sousa que afirma que na véspera da independência, governadas por capitães-generais existiam: "Pernambuco, Bahia, Rio de Janeiro, S. Paulo, Rio-Grande do Sul (compreendendo o governo das Missóes do Uruguay), Minas Gerais, Matto-Grosso e Goyaz" (Augusto Fausto de Sousa. Estudo sobre a divisão territorial do Brasil, op. cit., p. 44). Além delas, administrados por simples governadores ou capitães-mores: "[...] Ceará, Rio-Grande do Norte, Parayba, Alagôas, Sergipe, Espírito-Santo e Santa Catharina" (SOUSA, Augusto Fausto de. Estudo sobre a divisão territorial do Brasil. Revista do IHGB, v. 43, n. 2, p. 42-44, 1880). Hélio Viana diz que as capitanias gerais (principais) foram: Pernambuco, Bahia de Todos os Santos, Rio de Janeiro e São Paulo e as subalternas: Rio Grande do Norte, Paraíba (autônoma desde 1799), Espírito Santo, Santa Catarina (Hélio Viana. Liquidação da donatarias, op. cit., p. 148).

${ }^{117}$ Algumas capitanias menores ou territórios nomeados como tal, em certa medida ausentes da documentação, áreas que demandam estudos que esclareçam sua real situação, não foram incluídas, como Paraguassu, Itaparica e Tamarandiva. Ver a esse respeito: Felisbello Freire. História territorial do Brazil, op. cit., p. 15-19.
} 


\begin{tabular}{|c|c|c|c|}
\hline \multicolumn{4}{|c|}{ CAPITANIAS DO ESTADO DO BRASIL (século XVII) } \\
\hline $\begin{array}{l}\text { CAPITANIA } \\
\text { PRINCIPAL }\end{array}$ & ANEXAS & ESTATUTO & DONATÁRIO \\
\hline \multirow{3}{*}{$\begin{array}{l}\text { Pernambuco } \\
\text { (Capitania here- } \\
\text { ditária dos condes } \\
\text { do Vimioso) }\end{array}$} & Itamaracá & Capitania de donatário & Marquês de Cascais \\
\hline & Alagoas & Capitania da Coroa & \\
\hline & $\begin{array}{c}\text { Rio de São Fran- } \\
\text { cisco }\end{array}$ & Capitania da Coroa & \\
\hline \multirow{6}{*}{ Bahia } & Paraíba & Capitania da Coroa & \\
\hline & $\begin{array}{l}\text { Rio Grande do } \\
\text { Norte }\end{array}$ & Capitania da Coroa & \\
\hline & Sergipe del Rey & Capitania da Coroa & \\
\hline & Ilhéus & Capitania de donatário & $\begin{array}{l}\text { D. António José de Castro, con- } \\
\text { de de Resende e almirante do } \\
\text { reino (último donatário) }\end{array}$ \\
\hline & Porto Seguro & Capitania de donatário & Duque de Aveiro \\
\hline & Espírito Santo & Capitania de donatário & $\begin{array}{c}\text { António Luís da Câmara Couti- } \\
\text { nho (herdeiro do } 1^{\circ} \text { donatário) } \\
\text { Francisco Gil de Araújo (desde } \\
1675)\end{array}$ \\
\hline \multirow{3}{*}{ Rio de Janeiro } & Cabo Frio & Capitania da Coroa & \\
\hline & Paraíba do Sul & Capitania de donatário & Visconde de Asseca \\
\hline & São Paulo & Capitania de donatário & Marquês de Cascais \\
\hline
\end{tabular}

Também são reduzidos os estudos a respeito da hierarquia entre as capitanias e as relaçóes entre as principais e as anexas, apesar de a documentação, particularmente nas décadas seguintes à Restauração portuguesa, tratar desse tema em correspondência que aborda conflitos de jurisdiçáo envolvendo os poderes dos governantes ultramarinos, particularmente os governadores-gerais e os governadores das capitanias principais e a sua ingerência nas anexas.

A identificação da posição hierárquica, principais e anexas, consta de documentação diversa. Em março de 1654, em consulta do Conselho Ultramarino a d. João IV sobre o governo da capitania de Pernambuco após a expulsão dos holandeses, a sua posição superior é reconhecida ao afirmar-se que a "dita capitania, que he a principal". Mais importante, pela natureza do documento, são as cartas patentes dos governadores, como a que nomeou Bernardo de Miranda Henriques, governador de Pernambuco em 1667, que indicava ser o provimento para o governo da "capitania de Pernambuco e das mais anexas exceto a da Paraíba e Rio Grande por estarem sujeitas ao governo do Brasil". ${ }^{118}$

No regimento de Fernão de Sousa Coutinho, que, como já indicamos anteriormente, ordenou o governo dessa capitania, a fórmula utilizada é "Governador da Capitania de Pernambuco e das mais de sua jurisdição", ${ }_{119}$ apesar de, em outras passagens, encontrarmos

\footnotetext{
${ }^{118}$ ANTT - Chancelaria de D. Afonso VI, livro 20, fl. 172v.

${ }^{119}$ Anais da Biblioteca Nacional do Rio de Janeiro, doravante denominados ABNRJ, v. XXVIII, 1908 , p. 121.
} 
"nessa praça e suas anexas". ${ }^{120}$ Também na capitania do Rio de Janeiro encontramos essa situação indicada, quando os governadores se apresentavam como governantes do Rio de Janeiro e demais capitanias da Repartição Sul, ${ }^{121}$ mesmo quando esta não mais existia ou, como na carta de d. Pedro a Mathias da Cunha, onde, diz o rei: "Mathias da Cunha governador da cidade do Rio de Janeiro e mais terras da jurisdição dessa capitania[...]". ${ }^{122}$

Como já indicamos anteriormente, os governadores das capitanias principais e os capitães-mores das anexas, fossem elas hereditárias ou régias, eram nomeados sempre pelos monarcas, no caso das principais, e majoritariamente, no caso das anexas. Os governadores das capitanias principais prestavam o pleito \& menagem na corte, muitas vezes nas mãos do rei, enquanto a posse do governo acontecia na capitania, diante da Câmara e de principais da localidade.

Nas capitanias anexas, conforme a documentação, encontramos diversas cartas patentes com provimento de capitães-mores que deveriam prestar pleito \& menagem, assumindo o governo a eles atribuído, nas mãos dos governadores das capitanias principais aos quais estavam sujeitos. Essa é uma das diferenças entre os governadores das capitanias principais e das anexas, eram os primeiros originários de Portugal e para lá retornavam ao final do exercício do governo, eram também fidalgos, detentores de cargos e privilégios no reino, inclusive comendas. Ao passo que eram os capitães-mores, em número expressivo, indivíduos que viviam na América lusa e aqui fizeram sua carreira, muitos tendo servido na guerra em Pernambuco. Eram pessoas honradas, mas nem sempre fidalgos.

Exemplificamos com a carta patente de Francisco Gomes Ribeiro, provido capitão-mor de Cabo Frio por d. Pedro, príncipe regente, em 14 de dezembro de 1678, onde o monarca mandava "ao meu governador das capitanias do Rio de Janeiro lhe de posse delle e lho deixe servir e exercitar por dito tempo de três anos com mais enquanto lhe não for sucessor". ${ }^{123} \mathrm{Ou}$ então, a carta patente de António Botelho da Silva, provido capitão-mor de Itamaracá por d. Pedro, príncipe regente, em 13 de janeiro de 1681, onde estava instruído que o monarca mandava que o "governador de Pernambuco lhe de posse da dita capitania e o deixe servir e exercitar pelo tempo de três anos [...]". ${ }^{124}$

Por mais que o pleito \& menagem seja ao rei, prestado ao seu representante, o governador da capitania principal, a cerimônia de juramento era uma prática de sujeição e sinalizava para uma situação de hierarquia e diferenciação de poderes. Por força dessa hierarquia de poderes, as anexas eram submetidas às principais, como se depreende da carta régia de d. Pedro II escrita ao governador Afonso Furtado de Mendonça em dezembro de 1672 para

\footnotetext{
${ }^{120}$ Ibidem, p. 125.

${ }^{121}$ Ver: RIBEIRO, Mônica da Silva. Divisão governativa do Estado do Brasil e a Repartição do Sul. In: Anais do XII Encontro Regional de História ANPUH-Rio. Niterói, 2006.

${ }^{122}$ ANRJ - Códice 60, v. 2, f. 61v.

${ }^{123}$ ANTT - Chancelaria de D. Afonso VI, livro 32, fl. 198v.-199v.

${ }^{124}$ ANTT - Chancelaria de D. Afonso VI, livro 39, f. 361v.
} 
resolver dúvidas quanto às jurisdições sobre a capitania de Itamaracá, anexa de Pernambuco, motivo de atrito entre governadores-gerais, inclusive Afonso Furtado de Mendonça e o governador Fernando de Souza Coutinho. Diz o rei que "por conveniências muito do meu serviço fui servido resolver que a dita Capitania de Itamaracá seja subordinada ao Governo de Pernambuco, em quanto ao militar" 125 ficando o "que toca ao Governo ordinário da Justiça e Fazenda há de seguir a dita Capitania o mesmo que executavam até agora nos autos judiciais os Ministros da Justiça como faziam para a Relação da Bahia, e os da Fazenda ao Provedor-mor dela", ${ }^{126}$ ou seja, submetidos ao governo-geral da Bahia e os poderes e ofícios de Justiça e Fazenda lá estabelecidos. Assim sendo, continua o rei, a "Fernão de Souza Coutinho mando repreender dos excessos com que se houve, estranhando-os muito, por mandar prender ao capitão de Itamaracá por guardar a Vossa Ordem". ${ }^{127}$ Concluindo, as anexas eram submetidas às principais no militar, correndo os provimentos de ofício, quando da ausência da iniciativa régia, mesmos o de capitão-mor, por conta do governo-geral do Estado do Brasil. Essa situação também é constatada por frei Gaspar da Madre de Deus quanto à capitania de São Vicente/São Paulo que, segundo ele, esteve mais “sujeita aos Governadores do Rio de Janeiro nas matérias de Guerra" ${ }^{128}$

Concluindo nosso trabalho, chamo atenção para o fato de que não há produção de conhecimentos sem diálogo e crítica, atitude assumida ao longo deste artigo, particularmente quando se trata de um recorte da produção histórica secundarizado por algum tempo, como foi feito com a História política.

Nesse sentido, este artigo, estudo de História política e administrativa, articulada, como deve ser, com a história social e cultural, identificou e caracterizou as hierarquias existentes entre os poderes que atuaram no Estado do Brasil, diferenciando-os e afirmando a supremacia dos governadores-gerais em relação aos governos das capitanias principais e anexas, régias e de donatário. Demonstrou assim que, ao contrário do que se tem afirmado e reproduzido há algum tempo, a dinâmica de governo da monarquia pluricontinental portuguesa na sua conquista americana não se constituía num amontoado de leis e regras casuísticas e sem coerência, aplicadas a poderes, na prática, indefinidos e sem funçóes e hierarquias definidas. Essa análise contemporânea, fundamentada em concepçóes historiográficas da atualidade, não se sustenta nos relatos e na documentação de época.

Os governos da monarquia pluricontinental lusa da América, o Estado do Brasil, existiam porque cumpriam finalidades, se comportavam segundo as normas do direito e das práticas costumeiras de sua época, desempenhavam funçóes relevantes de governo e desfrutavam de qualificação social e poderes diversos que os hierarquizava. Essa é a contribuição

\footnotetext{
${ }^{125}$ DHBN, v. 67, p. 195.

${ }^{126}$ Idem.

${ }^{127}$ DHBN, v. 67, p. 195.

${ }^{128}$ MADRE DE DEUS, Frei Gaspar da. Memórias para a História da Capitania de S. Vicente, hoje chamada de São Paulo do Estado do Brasil. Lisboa: Typografia da Academia, 1797, p. 129-130.
} 
do nosso estudo, permitindo uma ampliação da compreensão da vida política e social do Estado do Brasil no século XVII, desvendando as relaçôes que se estabeleciam entre as diversas instâncias de poder e governo, o alcance de sua autoridade e seus limites, estabelecidos, não por ação episódica da monarquia lusa, mas sustentado nas instruçôes que constituem os diversos regimentos que regem os poderes e funçóes desses governos.

\section{Referências bibliográficas}

Documentação consultada

Biblioteca Nacional do Rio de Janeiro - BNRJ

Arquivo Nacional do Rio de Janeiro - ANRJ

Arquivo Público do estado da Bahia - APEB

Anais da Biblioteca Nacional do Rio de Janeiro - ABNRJ

Documentos Históricos do Arquivo Municipal da Bahia

Documentos Históricos da Biblioteca Nacional — DHBN

Biblioteca Nacional de Lisboa - BNL

Arquivo Nacional da Torre do Tombo - ANTT

Biblioteca da Ajuda — BA

Arquivo Histórico Ultramarino - AHU

Dicionários e obras de referência

BLUTEAU, D. Raphael. Vocabulario portuguez e latino. Rio de Janeiro: Universidade do Estado do Rio de Janeiro, s/d. CR-ROM, s/d.

Código Philippino. Rio de Janeiro: Typographia do Instituto Philomathico, 1870.

COVARRUBIAS, Sebastián de. Tesoro de la Lengua castellana o española (facsimil de 1943). Barcelona: Editorial Alta Fulla, 2003

MADRE DE DEUS, Frei Gaspar da. Memórias para a História da Capitania de S. Vicente, hoje chamada de São Paulo do Estado do Brasil. Lisboa: Typografia da Academia, 1797.

MENDONÇA, Marcos Carneiro de. Raizes da formação administrativa do Brasil. Rio de Janeiro: IHGB/Conselho Federal de Cultura, 1972.

Ordenaçoens do Senhor Rey D. Manuel. Coimbra: Real Imprensa da Universidade, 1797

PISSURLENCAR, Panduronga S. S. Assentos do Conselho do Estado, vol. I (1618-1633).

Goa (Bastorá): Tipografia Rangel, 1953. 
RAU, Virgínia; SILVA, Maria Fernanda Gomes da. Os Manuscritos do Arquivo da Casa de Cadaval respeitantes ao Brasil, vol. I. Coimbra: Acta Universitatis Conimbrigensis, 1955.

Recopilacion de Leyes de los Reynos de las Índias. Tomo I, libro III, tit. II. Madri: INBOE, 1998.

SALVADOR, Frei Vicente. História do Brasil. São Paulo: Melhoramentos, 1975.

SOUSA, Augusto Fausto de. Estudo sobre a divisão territorial do Brasil. Revista do IHGB, v. 43, n. $2,1880$.

Livros, capítulos e artigos

ABREU, Capistrano. Capitulos de História colonial. 7. ed. Belo Horizonte: Itatiaia; São Paulo: Publifolha, 2000.

ARAÚJO, Hugo André Flores Fernandes. Governação em tempo de guerra: governo geral do Estado do Brasil e a gestão da defesa (1642-1654). Dissertação (mestrado) — Programa de Pós-Graduação em História. Universidade Federal de Juiz de Fora, 2014.

ARTOLA, Miguel. La Monarquía de España. Madri: Alianza Editorial, 1999.

AVELLAR, Helio de Alcântara. História administrativa e econômica do Brasil. Rio de Janeiro: Fename, 1970.

BETHENCOURT, Francisco. Configuraçóes políticas e poderes locais. In: BETHENCOURT, Francisco; CURTO, Diogo Ramada. A expansão marítima portuguesa, 1400-1800. Lisboa/Portugal: Edições 70, 2010.

CALMON, Pedro. História do Brasil. As origens (1500-1600). São Paulo: Cia Editora Nacional, 1951, v. 1.

COSENTINO, Francisco Carlos. Governadores gerais do Estado do Brasil (séculos XVI-XVII): ofício, regimentos, governação e trajetórias. São Paulo: Annablume/FAPEMIG, 2009.

. Construindo o Estado do Brasil: instituições, poderes locais e poderes centrais. In: FRAGOSO, João; GOUVÊA, Maria de Fátima. O Brasil Colonial, 1443-1580. v. I. Rio de Janeiro: Civilização Brasileira, 2014, v.1.

. Fidalgos portugueses no governo geral do Estado do Brasil, 1640-1702. Revista do Instituto Histórico e Geographico Brazileiro, v. 173, p. 15-43, 2012.

. Governadores gerais do Estado do Brasil pós Restauração: guerra e carreira militar. Varia História, n. 48, Belo Horizonte, 2012.

- Monarquia pluricontinental, o governo sinodal e os governadores-gerais do Estado do Brasil. In: GUEDES, Roberto (Org.). Dinâmica imperial no Antigo Regime português. Rio de Janeiro: Mauad X/ ART, 2011, p. 67-82.

- O ofício e as cerimônias de nomeação e posse para o governo-geral do Estado do Brasil (séculos XVI e XVII). In: BICALHO, Maria Fernanda; FERLINI, Vera Lúcia Amaral 
(Org.). Modos de governar. Ideias e práticas políticas no império português. Séculos XVI a XIX. São Paulo: Alameda, 2005, p. 137-155.

CUNHA, Mafalda Soares da; MONTEIRO, Nuno Gonçalo. Governadores e capitãesmores do império atlântico português nos séculos XVII e XVIII. In: MONTEIRO, Nuno Gonçalo; CARDIM, Pedro; CUNHA, Mafalda Soares da (Orgs.). Optima Pars: elites iberoamericanas do Antigo Regime. Lisboa: ICS, 2005, p. 191-252.

DIAS, Manuel Nunes. O sistema das capitanias do Brasil. Boletim da Biblioteca da Universidade de Coimbra, v. XXXIV, 3. parte, 1980.

ELLIOTT, J. H. La Espana Imperial. 1469-1716. Barcelona: Ediciones Vicens-Vives, 1998. FAORO, Raymundo. Os donos do poder. 10. ed. São Paulo: Globo, 1996, v. 1.

FRANCO, Francisco de Assis Carvalho. Os capitães-mores vicentinos. São Paulo: Separata da Revista do Arquivo, n. LXV, 1940.

FREIRE, Felisbello. História territorial do Brazil. (Bahia, Sergipe e Espirito Santo). Salvador: Secretária da Cultura e Turismo/Instituto Geográfico e Histórico da Bahia, 1998, v. 1.

GUEDES, João Alfredo Libânio. História administrativa do Brasil. Da restauração a d. João V. 2. ed. Brasília/DF: Funcep, 1984, v. IV.

HESPANHA, António Manuel. Depois do Leviathan. In: Caleidoscópio do Antigo Regime. São Paulo: Alameda, 2012.

LADURIE, Emmanuel Le Roy. O Estado monárquico. França, 1460-1610. São Paulo: Companhia das Letras, 1995

LEVI, Lucio. Regime Político. In: BOBBIO, Norberto; MATTEUCCI, Nicola; PASQUINO, Gianfranco. Dicionário de Política. 5. ed. Brasília: EdUnb, 1993.

LOBO, Eulália Maria Lahmeyer. Processo administrativo ibero-americano. Rio de Janeiro: Biblioteca do Exército, 1962.

LOUREIRO, Marcello J. Gomes. A gestão do labirinto. Rio de Janeiro: Apicuri, 2012.

. Iustitiam Dare. A gestão da monarquia pluricontinental. Conselhos superiores, pactos, articulaçôes e o governo da monarquia portuguesa (1640-1668). Tese (doutorado) - Programa de Pós-Graduação em História Social, Instituto de História, Universidade Federal do Rio de Janeiro, 2013.

MONTEIRO, Nuno Gonçalo. D. Pedro II regente e rei (1668-1706). A consolidação da dinastia de Bragança. In: HESPANHA, António Manuel (Coord.). História de Portugal. O Antigo Regime. Lisboa: Editorial Estampa, 1998, v. 4.

NOVAIS, Fernando A. Estrutura e dinâmica do Antigo Sistema Colonial. 6. ed. Sáo Paulo: Brasiliense, 1993.

PRADO JUNIOR, Caio. Formação do Brasil contemporâneo. 14. ed. São Paulo: Brasiliense, 1976. 
PUJOL, Xavier Gil. Tiempo de política. Perspectivas historiográficas sobre la Europa moderna. Barcelona: Publicacions i Edicions Universitat de Barcelona, 2006.

PUNTONI, Pedro. O Estado do Brasil. Poder e política na Bahia colonial - 1548-1700. São Paulo: Editorial Alameda, 2013.

RIBEIRO, Mônica da Silva. Divisão governativa do Estado do Brasil e a Repartição do Sul. In: Anais do XII Encontro Regional de História ANPUH-Rio. Niterói, 2006.

RICUPERO, Rodrigo. A formação da elite colonial, Brasil c. 1530-c. 1630. São Paulo: Alameda Editorial, 2009.

RIVERO RODRÍGUEZ, Manuel. La edad de oro de los virreyes. Madri: Ediciones Akal, 2011.

RUBIO MAÑÉ, José Ignacio. El Virreinato, I Orígenes y jurisdicciones, y dinámica social de los virreyes. México: Fondo de Cultura Económica, 1992.

SALDANHA, António Vasconcelos de. As capitanias do Brasil. Antecedentes, desenvolvimento e extinção de um fenômeno atlântico. Lisboa: CNCDP, 2001.

SALGADO, Graça (Coord.). Fiscais e meirinhos. A administração no Brasil colonial. Rio de Janeiro: Nova Fronteira, 1985.

SERRÃO, Joaquim Veríssimo. História de Portugal. A Restauração e a Monarquia Absoluta (1640-1750). 2. ed. Lisboa: Editorial Verbo, 1982, v. V.

SOUZA, Laura de Mello. O sol e a sombra. Política e administração na América portuguesa do século XVIII. São Paulo: Companhia das Letras, 2006.

STONE, Lawrence. La crisis de la aristocracia, 1558-1641. Madri: Alianza Editorial, 1985.

TAUNAY, Afonso D’Escragnolle. História da cidade de São Paulo. São Paulo: Melhoramentos, 1953.

VARnHAGEN, Francisco Adolfo. História geral do Brasil. Tomo Primeiro. São Paulo: Melhoramentos, 1975.

VIANA, Hélio. Liquidação das donatarias. Revista do IHGB, v. 273, out./dez. 1966. 